\title{
The source kitchen of the Niger Delta oils: case study on Nembe Creek E1.0 and the Kolo Creek E2.0 reservoirs
}

\author{
Selegha Abrakasa ${ }^{1,2} \cdot$ Victor Ukaegbu $^{1} \cdot$ Mudiaga Onojake $^{3}$
}

Received: 26 March 2015/Accepted: 26 October 2015/Published online: 22 December 2015

(C) The Author(s) 2015. This article is published with open access at Springerlink.com

\begin{abstract}
The source kitchen of a petroleum system is that part of the pod of active source rock which is mature and generates the petroleum that charges the reservoir rock. The location of the source kitchen of a petroleum system is vital to the explorationist, its knowledge fosters the prediction of migratory pathways and the migratory losses prior to present times, also estimates potential volume of accumulation. Hither to, mapping of the petroleum basins was based on total organic carbon (TOC), hydrogen index (HI) signatures and maturity history of the source rock and has been used as the basis to suggest locations of petroleum kitchens. In contemporary times, 4D seismic or 3D time lapse geochemistry had been used to suggest location of source kitchen. However, settled is the concept of lateral maturity gradients, implying that within reservoir scales of a kilometer to tens of kilometers, regional petroleum emplacement direction could be deduced from subtle changes in maturity of successive charges of petroleum into the reservoir. In this study, the sterane isomerization ratio $\left(20 \mathrm{~S} / 20 \mathrm{~S}+20 \mathrm{R} \alpha \alpha \alpha \mathrm{C}_{29}\right)$ was used to determine the maturities of the hydrocarbons from various wells in the Kolo Creek and the Nembe Creek reservoirs. Subtle increases in maturities were observed to be in a NE-SW direction for the Kolo Creek reservoir and in a NW-SE direction for the Nembe Creek reservoir. The direction of
\end{abstract}

Mudiaga Onojake

ononed@yahoo.com

1 Department of Geology, University of Port Harcourt, Port Harcourt, Nigeria

2 Centre for Petroleum Geosciences, University of Port Harcourt, Port Harcourt, Nigeria

3 Department of Pure and Industrial Chemistry, University of Port Harcourt, Port Harcourt, Nigeria increasing maturities relative to the location of the reservoirs could be extrapolated for both reservoirs towards offshore Gulf of Guinea; this is invariably the direction of location of the source kitchen for the Niger Delta oils.

Keywords Hydrogen index - Maturity gradients - Source kitchens - Time lapse geochemistry - Total organic carbon

\section{Introduction}

Hydrocarbons are generated from source rocks, source rocks are one of the essential elements to a petroleum system. The existence of a petroleum system creates the quest for identification of the existence of a petroleum source kitchen. Every petroleum system has a source kitchen, identification of the location of the source kitchen or the direction of the source kitchen fosters better design considerations for exploration strategies, spudding of exploratory and production wells, development of oil fields and application of enhanced oil recovery techniques for fields with declined production rates.

In a study on the total organic carbon (TOC) of the sediments of the Niger and Benue Rivers and Niger Delta front (Wagner, Personal Communication 2004), it was observed that the river sediments had higher TOC relative to the Delta front; this was attributed to the upwelling process in the delta front (Tyson, Personal Communication 2004). The upwelling process brings the organic matter to shallow depths, where microorganism degrade the organic matter, invariably this results in low productive capacities of the Niger Delta source rocks (Evamy et al. 1978). However, the low productive capacity (fair total organic carbon and low to moderate hydrogen index) is compensated by the thick sequence of sediments comprising the 
Niger Delta source rocks. The growth fault provides good migration pathway for large volumes of oil and gas produced from the Niger Delta basin (Bustin 1998; Tuttle et al. 1999).

The implication of this observation is that previously TOC has been relied upon as a parameter for classification of sources rocks. Geochemical mapping of TOC contours over petroleum basins has been used to predict the location of hydrocarbon source kitchen; however, the hydrogen index (HI) concept further enhances the source kitchen prediction.

Time lapse geochemistry has been applied for prediction of hydrocarbon source kitchen, based on the fact that changes in oil saturation and hydrocarbon fingerprints overtime may indicate location of hydrocarbon source kitchen and migration direction of expelled hydrocarbon (Milkov et al. 2007).

\section{Geology and structural history}

The Niger Delta consists of about $12 \mathrm{~km}$ of thick sequence of clastic sediments which is about $75,000 \mathrm{~km}^{2}$ area in the Southern part of Nigeria. These deposits make up the basal Paleocene pro-delta facies which is the Akata formation, this is overlain by the Eocene paralic facies of the Agbada formation and in turn overlain by the Oligocene fluvial facies of the Benin formation (Evamy et al. 1978; Nyantakyi et al. 2013; Oboh 1993). The high sedimentation rates and low subsidence rate results in uncompacted, overpressure shales deposited during the transgressive regime resulting in the Akata formation. The deposition of the regressive Agbada formation resulted in the deposition of high-density sands overlaying the mobile uncompacted shales of Akata formation which fostered the progradation of the delta front seawards resulting in the development of growth faults which has been attributed to gravitational instability (Evamy et al. 1978; Tuttle et al. 1999).

The growth faults gave rise to antithetic and synthetic faults which result in the formation of rollover anticlines, shale ridges and diapers. They are formed as a result of load compaction and differential subsidence due to rapid sedimentation. The growth faults serve as migratory pathways for hydrocarbon emplacement into the structure. The distal part of the delta consists of marine shales which are characteristically overpressurized and hydrocarbons are emplaced from the marine shales into reservoir by episodic charging due to dissipation of overpressure via fracturing, healing of the fractures and refracturing (Tuttle et al. 1999).

The Nembe Creek (Fig. 1) is in the coastal swamp of the Niger Delta in the Oil Mining License (OML) for block 29.
The Nembe Creek reservoir (Fig. 1) is in the Middle Miocene deltaic sandstone-shale sequence. The structure is dissected by numerous growth faults steeping upwards. The shallow sandstone reservoirs are faulted such that spill points are generated at remarkable uniform depths resulting in similarity of fluid contact depth. A transgressive shale formation overlay the reservoir, which makes up the caprock (Nelson 1980).

The Kolo Creek oil field (Fig. 1) is an onshore oil field, the reservoir has been dated to the Middle Miocene using palynomorph assemblage and it has been identified to be deposited in the parasequence of shallow marine and deltaic plain deposits. The field is characterized by numerous predominantly E-W trending growth fault, both reservoirs are off the Middle Miocene and of the Agbada formation (Oboh 1993).

\section{Niger Delta source rocks}

The major source rocks in the Niger Delta are the Akata formation and the Agbada formation. However, there are controversies regarding the major contributing source rock generating the Niger Delta oils, hence two schools of thought exist on different and opposing hypothesis that Akata formation is the major source rock and vice versa (Nwachukwu and Chukwra 1986). The two major source rocks are the Agbada and Akata formations, their contributions to hydrocarbon generation have been in question with respect to their structural history (structural evolution over time), and maturity history. An independent study by the US geological survey (Tuttle et al. 1999) indicates that the oil window is just above the Akata formation and that a greater part of the Agbada formation (Upper Agbada formation) is immature, thus will not be able to generate hydrocarbons. This implies that the Akata formation is the major contributing source rock while the Agbada formation is the minor contributing source rock.

\section{The concept of lateral maturity gradients}

Source rock matures with continuous burial and subsidence, a producing source rock still undergoes burial which fosters continuous maturation. When hydrocarbon charges from the hydrocarbon kitchen arrive a reservoir, those gain access via a network of pores embedded in the matrix of the rocks or via fractures or faults, usually those bearing the lowest capillary entry pressure. The early arriving petroleum is usually in a series of fronts, depending on the reservoir dynamics, the arriving petroleum will occupy its position within the reservoir, later charges arriving will 


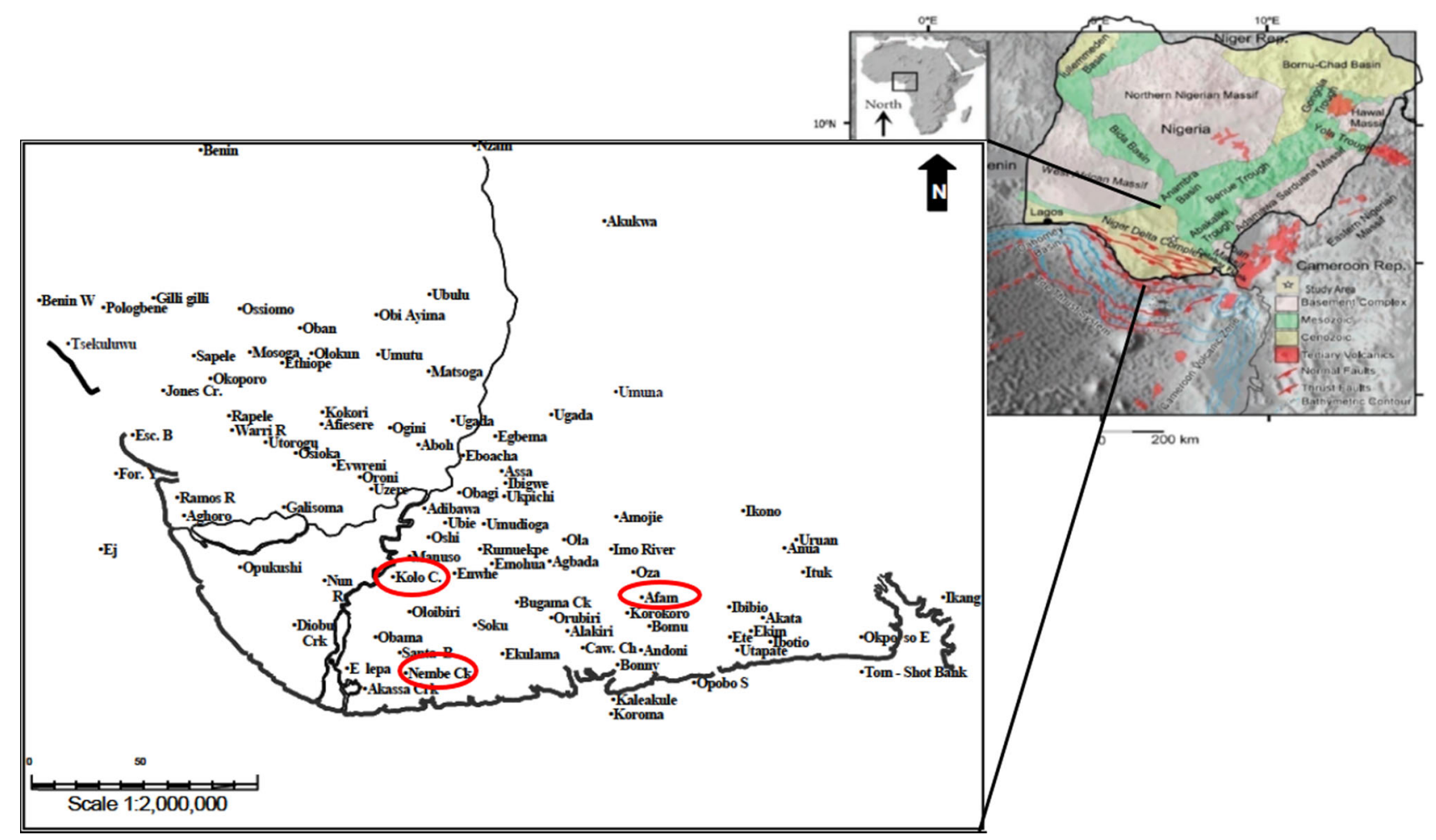

Fig. 1 Map of Nigeria; inset the Nigeria Delta Map showing locations of studied oil fields (Afam, Kolo Creek and Nembe Creek) in red colored circle. Modified from Amos-Uhegbu et al. 2013 and Akpabio et al. 2013

displace the earlier charges into reservoir (Larter and Aplin 1995). The earlier charges are generated and expelled from a less mature source rock in the kitchen, overtime as generation, expulsion and migration progresses the source rock in the kitchen undergoes subsidence and matures, hence later charges from the source rock into the reservoir are more mature than earlier charges, this results in lateral compositional variation and indeed subtle maturity differences expressed as a maturity gradient across the reservoir. The maturity gradient increases in the direction of the kitchen. Parameters such as GORs, biomarkers (maturity markers), water flow directions (n-alkane concentrations) and compositional step changes are employed for determining directions of source kitchens in basins (Larter and Aplin 1995).

\section{Samples and methods}

\section{Sampling}

A set of oil samples totaling sixteen (16) were obtained from different oil fields within the Niger Delta basin. Ten (10) samples were obtained from Kolo Creek field, four (4) oil samples were obtained from Nembe Creek field and two (2) oil samples from Afam oil field. All samples were obtained from the wellhead and serve as a true representative of the bulk. Samples were stored in glass vials and preserved in a refrigerator till the samples were required for analysis.

\section{Fractionation of oil samples}

Fractionation of the oil samples were consistent with procedures outlined in Abrakasa (2006). Oil samples were fractionated using chromatographic column $(50 \mathrm{~cm}$ in length, $0.5 \mathrm{~cm}$ internal diameter, supplied by BDH, England), which was packed with a stationary phase silica gel 60 size, $0.063-0.2 \mathrm{~mm}$ (70-230) mesh, $\left(\mathrm{SiO}_{2}\right)$ (AnalaR grade supplied by BDH, England) while the mobile phase was Light Petroleum Spirit $\left(30^{\circ}-40^{\circ}\right)$, (Pet Ether) (AnalaR grade supplied by BDH, England). The oils were blended with activated alumina and introduced into the column, the aliphatics and the aromatics were eluted using $70 \mathrm{ml}$ each of petroleum ether and dichloromethane (AnalaR grade supplied by BDH, England).

\section{GC, GC-MS analysis}

The fractions were subjected to GC analysis using HP3890GC serial II, separation was performed on a fused silica capillary column $(30 \mathrm{~m} \times 0.25 \mathrm{~mm}$ i.d.) coated with 
Table 1 The sterane isomerization values and corresponding vitrinite reflectance values

\begin{tabular}{lll}
\hline Sample & $20 \mathrm{~S} /(20 \mathrm{~S}+20 \mathrm{R})$ & $\mathrm{VR}$ \\
\hline SA02 & 0.41 & 0.66 \\
SA03 & 0.37 & 0.62 \\
SA15 & 0.40 & 0.66 \\
SA16 & 0.40 & 0.66 \\
SA19 & 0.36 & 0.61 \\
SA20 & 0.34 & 0.58 \\
SA22 & 0.45 & 0.73 \\
SA23 & 0.39 & 0.65 \\
SA25 & 0.37 & 0.62 \\
SA29 & 0.45 & 0.73 \\
NEM12 & 0.40 & 0.66 \\
NEM21 & 0.40 & 0.65 \\
NEM22 & 0.45 & 0.74 \\
OD22 & 0.45 & 0.72 \\
NEM11 & 0.47 & 0.77 \\
\hline
\end{tabular}

$0.25 \mu \mathrm{m}, 5 \%$ phenyl methyl silicone (HP-5) supplied by HP currently known as Agilent UK. Hydrogen gas was used as carrier gas at $2 \mathrm{ml} / \mathrm{min}$ with a spilt/splitless injector, the temperature was programmed at $50{ }^{\circ} \mathrm{C}$ for $2 \mathrm{~min}$ then progressed at $4{ }^{\circ} \mathrm{C} / \mathrm{min}$ to $300 \mathrm{C}$ at which it is held for $20 \mathrm{~min}$

The GC-MS analysis of the saturated hydrocarbon was performed for the purpose of monitoring some fragment ions of some molecular marker compounds on a HewlettPackard $5890 \mathrm{II}$ GC with a split/splitless injector $\left(280{ }^{\circ} \mathrm{C}\right)$ linked to a Hewlett-Packard 5972MSD with electron voltage of $70 \mathrm{eV}$, filament current of $220 \mu \mathrm{A}$, source temperature of $160{ }^{\circ} \mathrm{C}$, a multiplier voltage $1600 \mathrm{~V}$ and interface temperature $300{ }^{\circ} \mathrm{C}$. The acquisition was controlled by an HP Vectra 48 PC chemstation computer in both full scan mode and selected ion mode (30ions $0.7 \mathrm{cps}$ $35 \mathrm{~ms}$ dwell) for greater sensitivity. Separation was performed on a fused silica capillary column $(30 \mathrm{~m} \times 0.25 \mathrm{~mm}$ i.d.) coated with $0.25 \mu \mathrm{m}, 5 \%$ phenyl methyl silicone (HP-5), supplied by HP currently known as Agilent, UK. The acquisition was controlled by a HP Compaq computer using Chemstation software, initially in full scan mode (50-600 amu/s) or in selected ion mode (30 ions $0.7 \mathrm{cps} 35 \mathrm{~ms}$ dwell) The GC was temperature programmed for $40-300{ }^{\circ} \mathrm{C}$ at $4{ }^{\circ} \mathrm{C}$ per minute and held as final temperature for $20 \mathrm{~min}$. The carrier gas is Helium (flow $1 \mathrm{ml} / \mathrm{min}$., pressure of $50 \mathrm{kPa}$, slit at $30 \mathrm{ml} / \mathrm{min}$.).

Peak integration was done manually and steranes were used as recommended for maturity assessments (Tissot and
Welte 1984; Zumberge 1987). Identification was achieved by matching with chromatogram of standards.

\section{Procedure for PCA analysis}

The principal component Analysis was performed as factor analysis using 14 biomarker ratios (variables) obtained from GC-MS analysis of the 16 crudes oil samples from Nembe Creek Oil field, Kolo Creek Oil field and Afam Oil field (Table 2). The first two factors were extracted; the extraction method employed was Principal Component Analysis (PCA). Varimax rotation was applied for maximum variation. The variations explained by the factors were $46.2 \%$ for the first factor and $30.0 \%$ for the second factor. The first two factors explained $76.2 \%$ of the variations and the plot obtained is the score plot (Fig. 5). The objective of performing the PCA plot is to obtain a finer resolution of discriminant analysis which fosters a better understanding of the relationship between within the oil fields and between the oil fields.

\section{Sterane isomerization ratios}

The sterane isomerization ratios $\left(20 \mathrm{~S} /(20 \mathrm{~S}+20 \mathrm{R}) \alpha \alpha \alpha \mathrm{C}_{29}\right.$ sterane) in Table 1 represent the maturity of the crude oils as represented by Zumberge (1987) and Tissot and Welte (1984) for immature to moderately mature oils. The ratio used is recommended for immature to moderately mature oils, the Niger Delta oils are moderately matured. The sterane isomerization ratios were calculated from the peak area derived from the percent report obtained from the chemstation. The ratios are then converted to the equivalent vitrinite reflectance values using the formula $(\mathrm{VR}=0.49(20 \mathrm{~S} / 20 \mathrm{R})+0.33)$ where $\mathrm{VR}$ is vitrinite reflectance (Zumberge 1987). The vitrinite reflectance values were posted on the isopach map against the corresponding wells where oil samples were obtained from the well head. The trend of the vitrinite reflectance data indicates the direction of petroleum emplacement into the reservoir, hence the direction of the source kitchen.

\section{Discussion}

\section{Geochemical characteristics}

The GC fingerprint in Fig. 2 is that of Kolo Creek oil, it shows that the oil has lost some of the lighter hydrocarbon fractions, the $m / z=217$ and $m / z=218$ are the mass chromatograms for the $\alpha \alpha \alpha$ and $\alpha \beta \beta$ cholestane series, the 

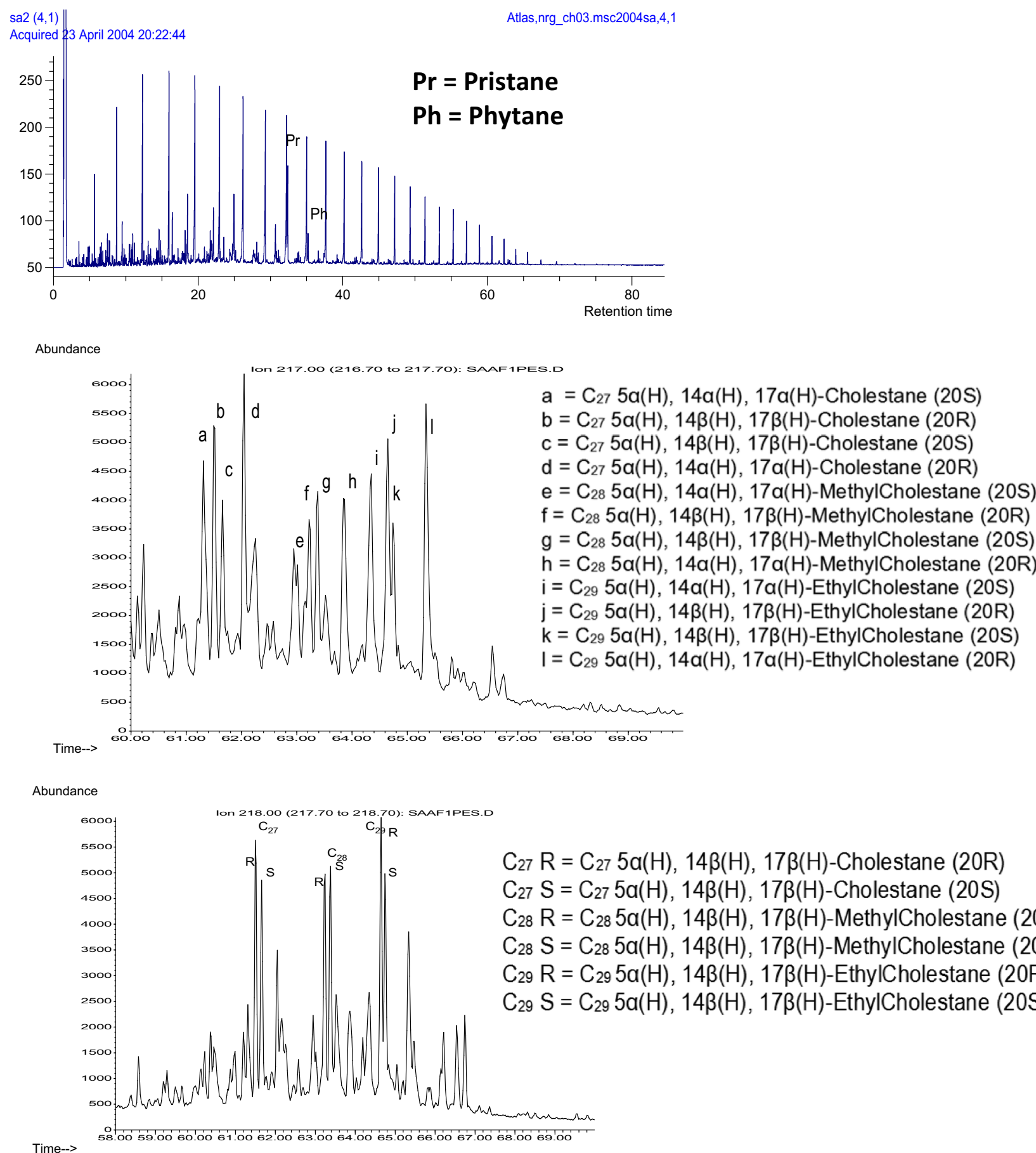

Fig. 2 A GC fingerprint of Afam Oil, $M / Z 217$ mass chromatogram and $M / Z=218$ mass chromatogram of Afam oil and the nomenclature of their corresponding peaks. The $\alpha \beta \beta$ peaks in the $m / z, 218$ exist as a doublet

position of the $\alpha \beta \beta$ (S\&R) doublet helps to locate the $\alpha \alpha \alpha$ peaks in the mass chromatogram. Figure 3 shows the overlay of the mass chromatograms for the $\mathrm{m} / \mathrm{z}=217, \mathrm{~m} /$ $z=218$ and $m / z=191$ for Nembe Creek sample 12. This overlay shows the relative positions of the peaks based on the number of carbon atoms in the compounds. This technique is used as one of the methods of double checking peak identification from the chemstation print out.

The ternary plot (Fig. 4) shows the clustering of the oils, this observation implies that Kolo Creek and the Nembe Creek oils show similar geochemical characteristics as indicated by the Steranes ternary plot (Fig. 4). Mackenzie 


\section{Abundance}

Ion 217.00 216.70 10217.70): am12.01dams

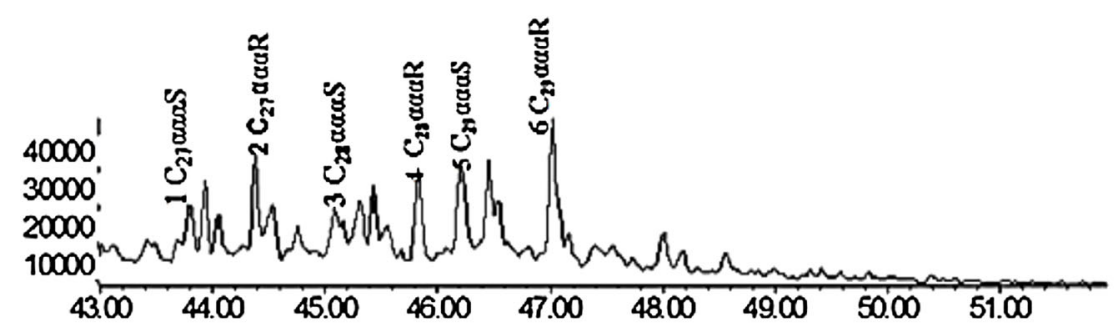

Time $\rightarrow$

Abundance
$1 \mathrm{C}_{27 \mathrm{aaaS}}=\mathrm{C}_{27} \mathrm{5a}(\mathrm{H}), 14 \mathrm{a}(\mathrm{H}), 17 \mathrm{a}(\mathrm{H})$-Cholestane $(20 \mathrm{~S})$

$2 \mathrm{C}_{27 \mathrm{aaaR}}=\mathrm{C}_{27} 5 \mathrm{a}(\mathrm{H}), 14 \mathrm{a}(\mathrm{H}), 17 \mathrm{a}(\mathrm{H})$-Cholestane (20R)

$3 \mathrm{C}_{28} \mathrm{aaaS}=\mathrm{C}_{28} 5 \mathrm{a}(\mathrm{H}), 14 \mathrm{a}(\mathrm{H}), 17 \mathrm{a}(\mathrm{H})$-MethylCholestane (20S)

$4 \mathrm{C}_{28} \mathrm{aaaR}=\mathrm{C}_{28} 5 \mathrm{a}(\mathrm{H}), 14 \mathrm{a}(\mathrm{H}), 17 \mathrm{a}(\mathrm{H})$-MethylCholestane $(20 \mathrm{R})$

$5 \mathrm{C}_{29} \mathrm{aaaS}=\mathrm{C}_{29} 5 \mathrm{a}(\mathrm{H}), 14 \mathrm{a}(\mathrm{H}), 17 \mathrm{a}(\mathrm{H})$-EthylCholestane $(20 \mathrm{~S})$ $6 \mathrm{C}_{29} \mathrm{aaaR}=\mathrm{C}_{29} 5 \mathrm{a}(\mathrm{H}), 14 \mathrm{a}(\mathrm{H}), 17 \mathrm{a}(\mathrm{H})$-EthylCholestane (20R)

$7 \mathrm{C}_{27} \mathrm{a} \beta \beta$ (Doublet) $=\mathrm{C}_{27} 5 \alpha(\mathrm{H}), 14 \beta(\mathrm{H}), 17 \beta(\mathrm{H})$-Cholestane (20R \& 20S)

$8 \mathrm{C}_{28} \mathrm{a} \beta \beta$ (Doublet) $=\mathrm{C}_{23} 5 \mathrm{a}(\mathrm{H}), 14 \beta(\mathrm{H}), 17 \beta(\mathrm{H})$-MethylCholestane (20R \& 20S)

$9 \mathrm{C}_{22 \mathrm{a} \beta} \mathrm{B}$ (Doublet) $=\mathrm{C}_{23} 5 \mathrm{a}(\mathrm{H}), 14 \beta(\mathrm{H}), 17 \beta(\mathrm{H})$-EthylCholestane (20R \& 20S)

$10 \mathrm{C}_{25} \mathrm{aaa} \mathrm{S}=\mathrm{C}_{22} 5 \mathrm{a}(\mathrm{H}), 14 \mathrm{a}(\mathrm{H}), 17 \mathrm{a}(\mathrm{H})$-EthylCholestane (20S)

$11 \mathrm{C}_{22} \mathrm{H}$ opane $=\mathrm{C}_{29} 17 \mathrm{a}(\mathrm{H}), 21 \beta(\mathrm{H})-30$-Norhopane

12 Oleanane $=\mathrm{C}_{30} 18 \mathrm{a}(\mathrm{H})$ Oleanane

$13 \mathrm{C}_{30}$ Hopane $=17 \mathrm{a}(\mathrm{H}), 21 \mathrm{\beta}(\mathrm{H})$-Hopane

Time $\rightarrow$

Abundance
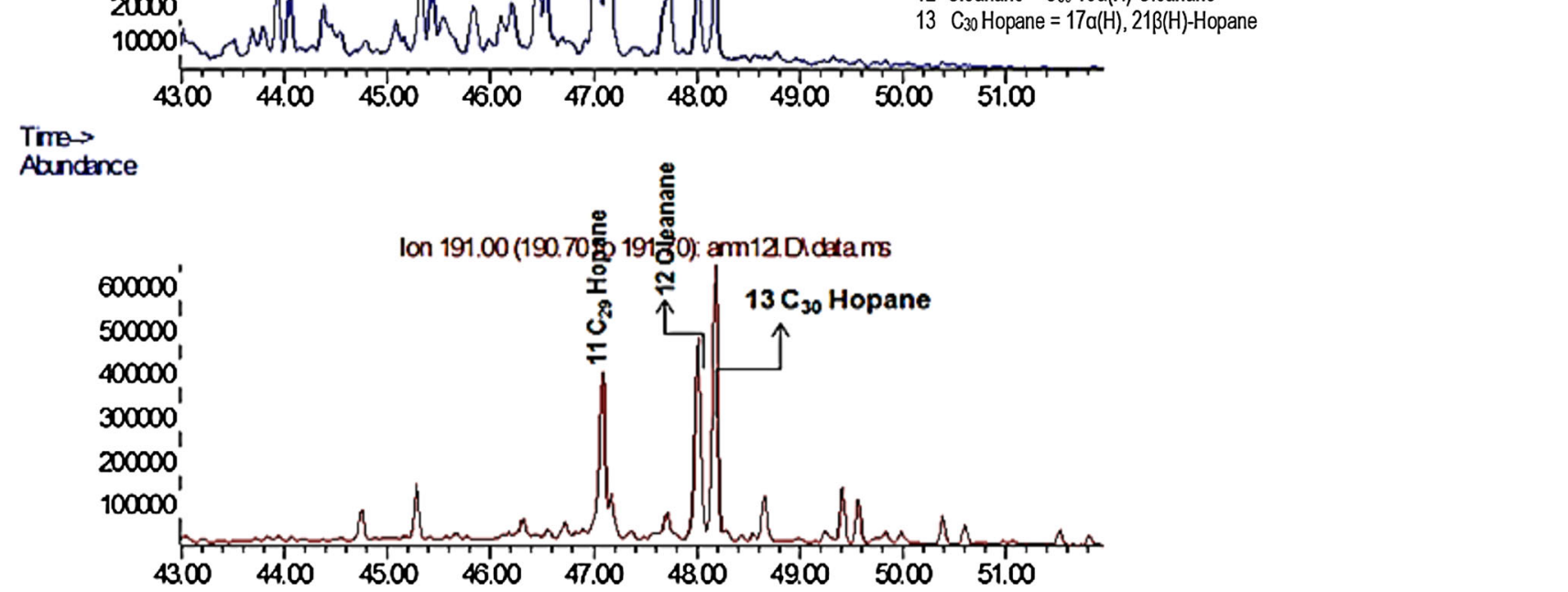

Time $\rightarrow$

Fig. 3 Overlay of the $M / Z=217$ mass chromatogram, $M / Z=218$ mass chromatogram and $M / Z=191$ mass chromatogram showing the position of the $\alpha \beta \beta$ doublet of the Cholestane series on the $M /$
$Z=218$ mass chromatograms which helps to locate the $\alpha \alpha \alpha$ Cholestane analogs on the $M / Z=217$ mass chromatograms

marine to estuarine (coastal marine) environment (Mackenzie 1984; Shanmugam 1985), where sea water mixes with drainages from continental supplies.

However, the principal component analysis is a statistical technique which fosters a better understanding of the relationships between samples and it is normally employed to reduce numerous data sets (Table 2) to a few sets of variables within which the most relevant information is condensed. The application of principal component 
Fig. 4 Ternary plot of steranes ratios for Nembe Creek, Kolo Creek and Afam fields

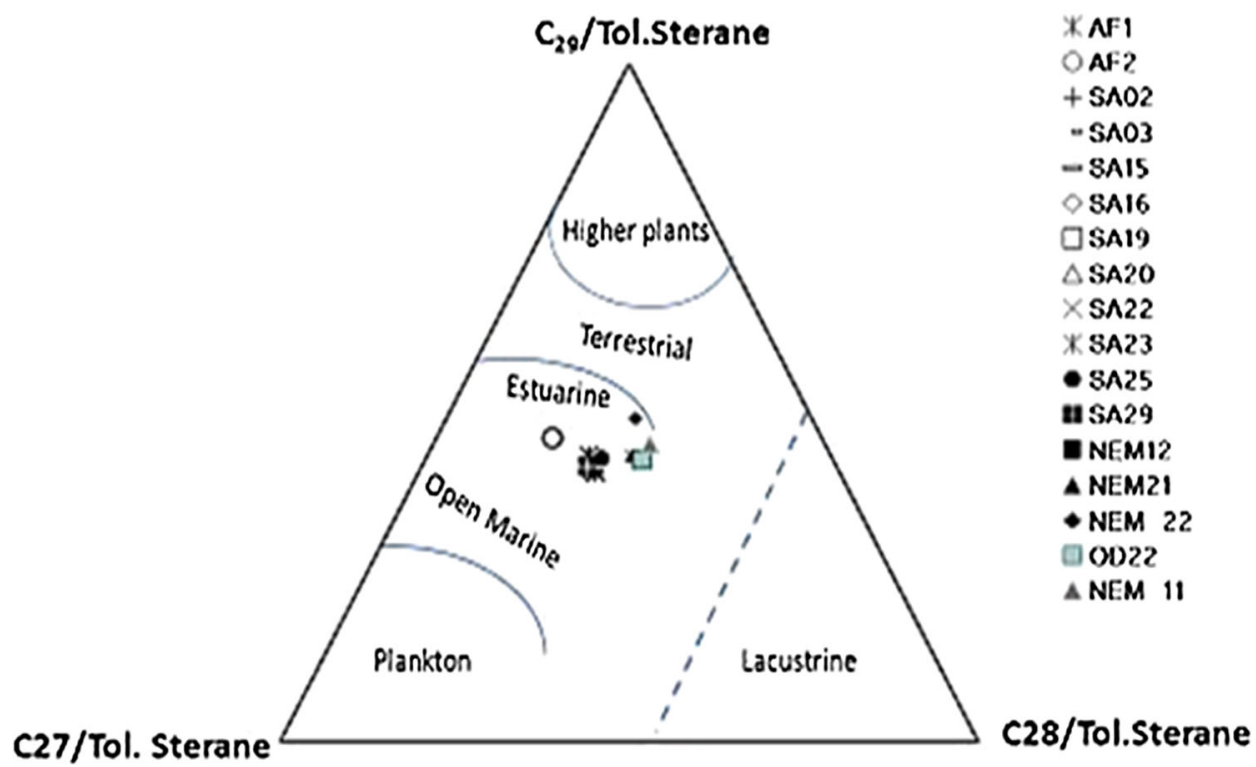

Table 2 Ratios used for principal component analysis (PCA) and the full names of the compounds

\begin{tabular}{lllllllllllllll}
\hline Samples & 1 & 2 & 3 & 4 & 5 & 6 & 7 & 8 & 9 & 10 & 11 & 12 & 13 \\
\hline AF1 & 0.295 & 0.932 & 1.081 & 0.473 & 0.590 & 0.789 & 0.455 & 0.738 & 0.957 & 2.759 & 0.176 & 0.082 & 0.705 & 0.072 \\
AF2 & 0.298 & 0.933 & 1.027 & 0.487 & 0.582 & 0.783 & 0.464 & 0.755 & 1.062 & 3.086 & 0.195 & 0.124 & 0.720 & 0.064 \\
SA02 & 0.473 & 0.958 & 1.566 & 0.506 & 0.585 & 1.095 & 0.405 & 0.664 & 2.076 & 4.123 & 0.189 & 0.119 & 0.739 & 0.075 \\
SA03 & 0.459 & 0.361 & 1.536 & 0.508 & 0.574 & 1.019 & 0.370 & 0.618 & 2.016 & 4.429 & 0.174 & 0.208 & 0.821 & 0.075 \\
SA15 & 0.460 & 0.959 & 1.651 & 0.493 & 0.580 & 0.977 & 0.404 & 0.661 & 1.948 & 4.350 & 0.189 & 0.122 & 0.753 & 0.075 \\
SA16 & 0.489 & 0.959 & 1.428 & 0.529 & 0.566 & 1.056 & 0.400 & 0.656 & 2.057 & 4.194 & 0.208 & 0.119 & 0.720 & 0.077 \\
SA19 & 0.455 & 0.960 & 1.534 & 0.492 & 0.573 & 1.006 & 0.360 & 0.606 & 2.065 & 4.495 & 0.176 & 0.117 & 0.764 & 0.079 \\
SA20 & 0.432 & 0.960 & 1.855 & 0.485 & 0.565 & 0.923 & 0.336 & 0.577 & 1.875 & 4.628 & 0.175 & 0.217 & 0.845 & 0.075 \\
SA22 & 0.460 & 0.959 & 1.357 & 0.516 & 0.581 & 1.092 & 0.448 & 0.727 & 2.126 & 4.307 & 0.201 & 0.108 & 0.780 & 0.077 \\
SA23 & 0.525 & 0.978 & 2.509 & 0.479 & 0.560 & 0.959 & 0.394 & 0.649 & 1.973 & 4.621 & 0.171 & 0.216 & 0.809 & 0.075 \\
SA25 & 0.454 & 0.957 & 1.778 & 0.491 & 0.557 & 0.926 & 0.371 & 0.618 & 1.895 & 4.472 & 0.185 & 0.134 & 0.760 & 0.079 \\
SA29 & 0.473 & 0.960 & 1.619 & 0.502 & 0.581 & 1.060 & 0.450 & 0.731 & 2.247 & 4.328 & 0.195 & 0.138 & 0.767 & 0.078 \\
NEM12 & 0.592 & 0.855 & 1.298 & 0.409 & 0.405 & 0.887 & 0.404 & 0.662 & 1.902 & 3.573 & 0.151 & 0.261 & 0.765 & 0.109 \\
NEM21 & 0.614 & 0.855 & 1.498 & 0.413 & 0.561 & 0.882 & 0.399 & 0.655 & 2.198 & 3.764 & 0.192 & 0.186 & 0.738 & 0.118 \\
NEM22 & 0.557 & 0.830 & 1.122 & 0.402 & 0.449 & 0.871 & 0.453 & 0.735 & 1.479 & 2.754 & 0.141 & 0.202 & 0.801 & 0.115 \\
NEM11 & 0.656 & 0.862 & 1.364 & 0.432 & 0.464 & 1.001 & 0.472 & 0.769 & 2.278 & 3.552 & 0.163 & 0.225 & 0.740 & 0.108 \\
\hline
\end{tabular}

$1 \mathrm{TPP} v \alpha \beta \mathrm{C}_{2 \mathrm{~s}}=17 \alpha, 21 \beta$-c30-norhopane

2 Hop/Hop+20R $\mathrm{C}_{29}$ sterane $\beta \alpha \mathrm{C}_{29} \mathrm{Dia}=17 \beta, 21 \alpha$-30-normoretane

$3 \mathrm{C}_{2 \mathrm{~g}} / \mathrm{C}_{27}$ sterane $\mathrm{C}_{2 \mathrm{~s}} \mathrm{Ts}=18 \alpha, 17 \alpha$-methyl-28,30 dinorhopane

$4 \mathrm{Ts} / \mathrm{Ts}+\mathrm{Tm} \mathrm{Tm}=17 \alpha, 21 \beta,-22,29,30$-trisnorhopane

$5 \mathrm{~S} / \mathrm{S}+\mathrm{R}$ al3 CjiHopane $\mathrm{Ts}=18 \alpha, 21 \beta-22,29,30$-trisnorhopane

6 oleanane $/$ CjoHopane $c_{30}$ hopane $=17 \alpha, 21 \beta$-hopane

$7 \mathrm{~S} / \mathrm{S}+\mathrm{R}$ aaaC ${ }_{29}$ ethyl cholestane $a_{a a C}{ }_{29}$ sterane $=\mathrm{C}_{29} 5 \alpha(\mathrm{H}), 14 \alpha(\mathrm{H}), 17 \alpha(\mathrm{H})$-ethyl cholestane

$8 \mathrm{VR} \%$ equivalent $\mathrm{C}_{29}$ sterane $=\mathrm{C}_{28} 5 \alpha(\mathrm{H}), 14 \alpha(\mathrm{H}), 17 \alpha(\mathrm{H})$-methyl cholestane $(20 \mathrm{~S})$

9 oleanane/sterane $\mathrm{C}_{27}$ sterane $=\mathrm{C}_{27} 5 \alpha(\mathrm{H}), 14 \alpha(\mathrm{H}), 17 \alpha(\mathrm{H})$-criolestane (20S)

10 hopane/sterane 20R $\mathrm{C}_{29}$ sterane $=\mathrm{C}_{29} 5 \alpha(\mathrm{H}), 14 \alpha(\mathrm{H}), 17 \alpha(\mathrm{H})$-EthylCholestane $(\mathrm{R})$

$11 \mathrm{C}_{29} \mathrm{Ts} / \mathrm{C}_{29} \mathrm{Ts}+\beta \alpha \mathrm{C}_{29}$ dia moretane $=17 \beta, 21 \alpha$-moretane

$12 \beta \alpha \mathrm{C}_{29} / \alpha \beta \mathrm{C}_{29} \alpha \beta \mathrm{C}_{31}$ hopane $=17 \alpha, 21 \beta$-30-homohopane $(22 \mathrm{~S}+22 \mathrm{R})$

$13 \alpha \beta \mathrm{C}_{29} / \alpha \beta \mathrm{C} 3 \mathrm{o}$ hopane $=$ Total of extended hopane

14 moretane/hopane TPP $=$ tetracyclic polyprenoids. sterane $=$ cholestane $(\mathrm{S}+\mathrm{R})+$ methyl cholestane $(\mathrm{S}+\mathrm{R})+$ ethylcholestane $(\mathrm{S}+\mathrm{R})$. Oleanane $=\mathrm{C}_{30}$ 18a $(\mathrm{H})$ oleanane 
analysis in this study discriminated the oils into three different family groups, which reflected their primary oil fields (Fig. 5). This infers that oils have subtle differences which could not be recognized without multivariate analysis (Fig. 5).

The maturity data in Table 1 show that the Nembe Creek oils are slightly more mature relative to the Kolo Creek oils; ratios indicate that the source kitchen had just gone beyond the oil window at the time of generation, while the Kolo Creek oils were generated when the source kitchen was just about to enter the oil window. It invariably implies that the Kolo Creek oils were generated and expelled before the Nembe Creek oils were generated.

\section{Petroleum emplacement direction}

The petroleum emplacement direction is the direction of the charging petroleum fronts or the direction of migration of petroleum into the reservoirs. The direction is deduced from the lateral maturity gradients across the reservoirs (Figs. 6,7), the gradient is identified by subtle increase in maturity of the oils from one oil well to another across the reservoir. The increase is always towards the direction of entry of petroleum into the reservoir. Figure 6 is an isopach map of the reservoir area of Kolo Creek Oil field. The maturity values are shown close to the well where the oils were obtained. A maturity gradient is observed, which indicates that the petroleum emplacement direction is in a
SW-NE direction across the reservoir. The maturity values (expressed as percentages of sterane isomerization ratios $\left(20 \mathrm{~S} /(20 \mathrm{~S}+20 \mathrm{R}) \quad \alpha \alpha \alpha \mathrm{C}_{29} \quad\right.$ Sterane $)$ gradually decrease from 44.76 at well 29 in the Southwestern part of the field to 36.01 at well 19 in the Northeastern part of the field. The gradient shows a gradual but significant change. Figure 7 is the isopach map of reservoir of Nembe Creek Oil field, the isomerization ratios for maturity decreases from 47.0 to 40.0. This observation implies that the petroleum emplacement direction is the SE-NW direction across the reservoir. Both Kolo Creek reservoir (Fig. 6) and the Nembe Creek reservoir (Fig. 7) show that the charging directions are from the Southern part of the oil fields.

The Nembe Creek and the Kolo Creek reservoirs were both deposited in the Middle Miocene, in Niger Delta basin, the source rocks which are the Akata and Agbada formations were deposited in the Paleocene and Eocene, respectively (Evamy et al. 1978; Nyantakyi et al. 2013; Oboh 1993) before deposition of the Niger Delta reservoirs. Nonetheless, the record of event (Haack et al. 2000) indicates that the reservoirs were in place before migration began. The maturity history as reflected by the vitrinite reflectance data (Tuttle et al. 1999) indicates that part of the Lower Agbada is above the oil window while the Upper Akata formation is within the oil window.

The structural history of the Niger Delta indicates continued progradation delta seaward corresponding to creation of growth fault due to gravity sliding (Evamy et al. 1978);
Fig. 5 The Principal component Analysis score plot for the Nembe Creek, Kolo Creek and the Afam oils

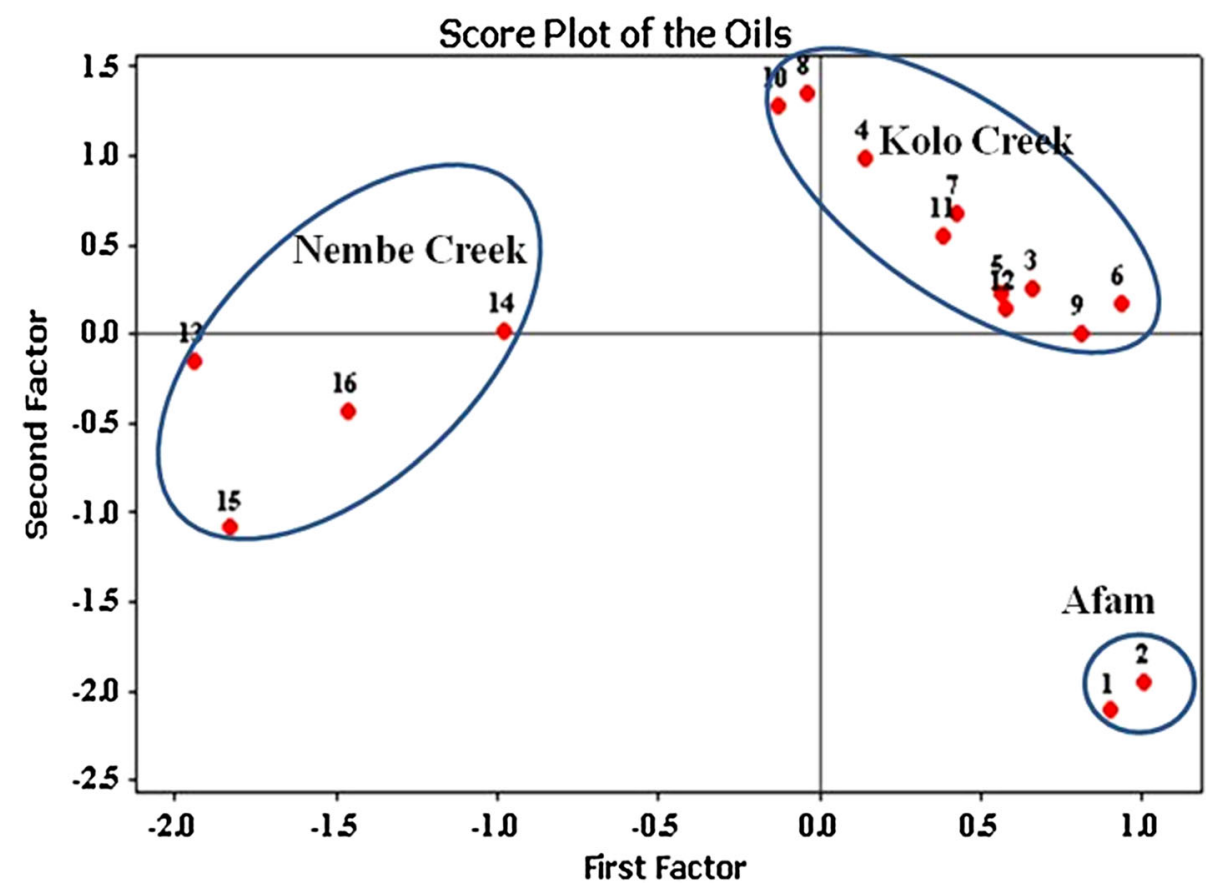


Fig. 6 Isopach map of Kolo Creek E2.0 reservoir showing the sterane maturity values indicating the direction of petroleum emplacement into the reservoir in a SW-NE trend (Modified from Oboh 1993)

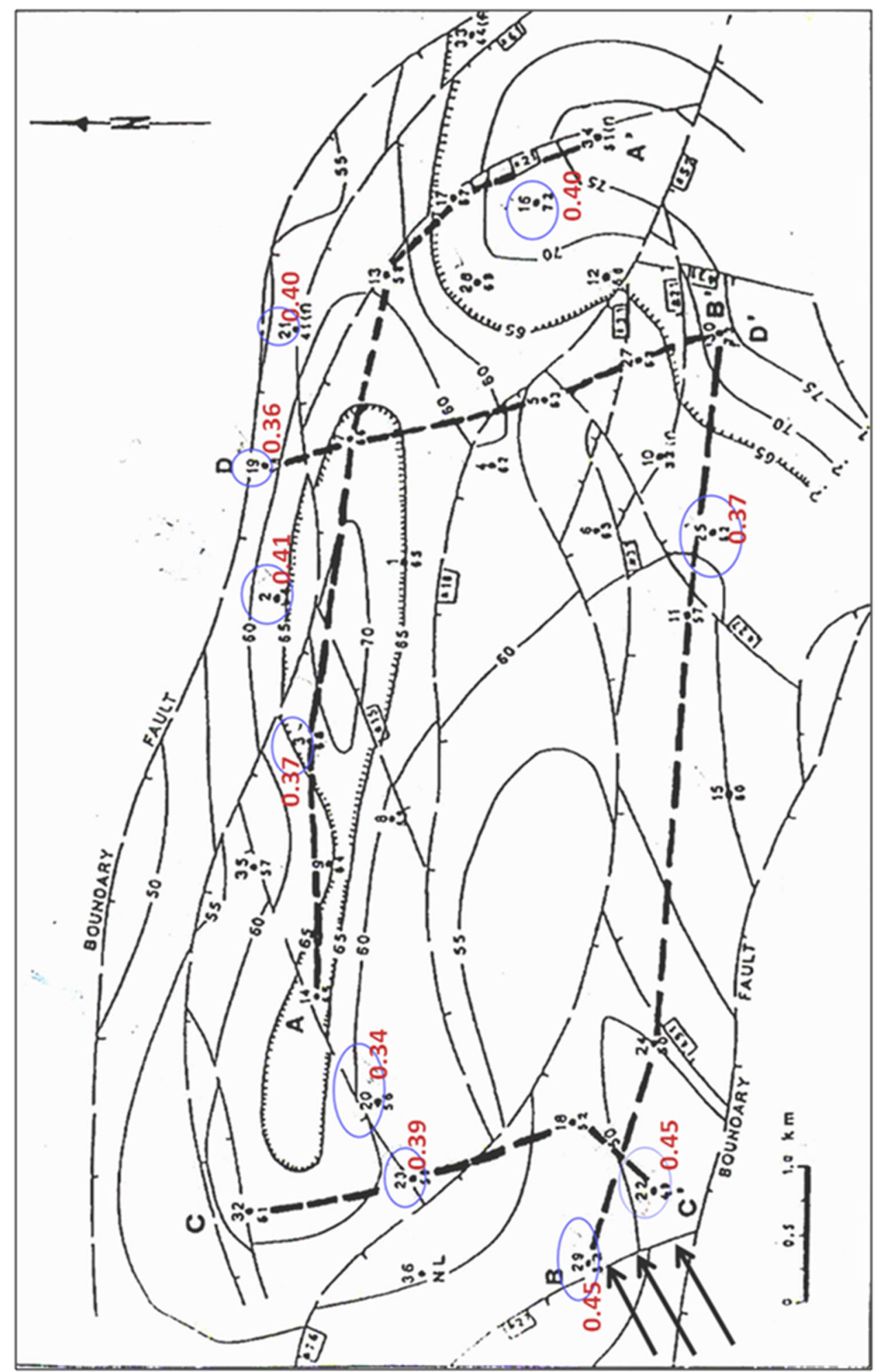

this is the main depositional mechanism in the Niger Delta. The overburden pressure of high-density Eocene and Miocene sand on the uncompacted, unlithified mobile shale results in the progradation, hence occurrence of source rock in distal marine setting of the Niger Delta. This is suggested to be the source of the petroleum charging the Kolo Creek and Nembe Creek reservoirs. The Nembe Creek reservoir is situated much more seaward than the Kolo Creek reservoir and the Nembe Creek reservoir bears more mature petroleum, the lateral maturity concept holds 


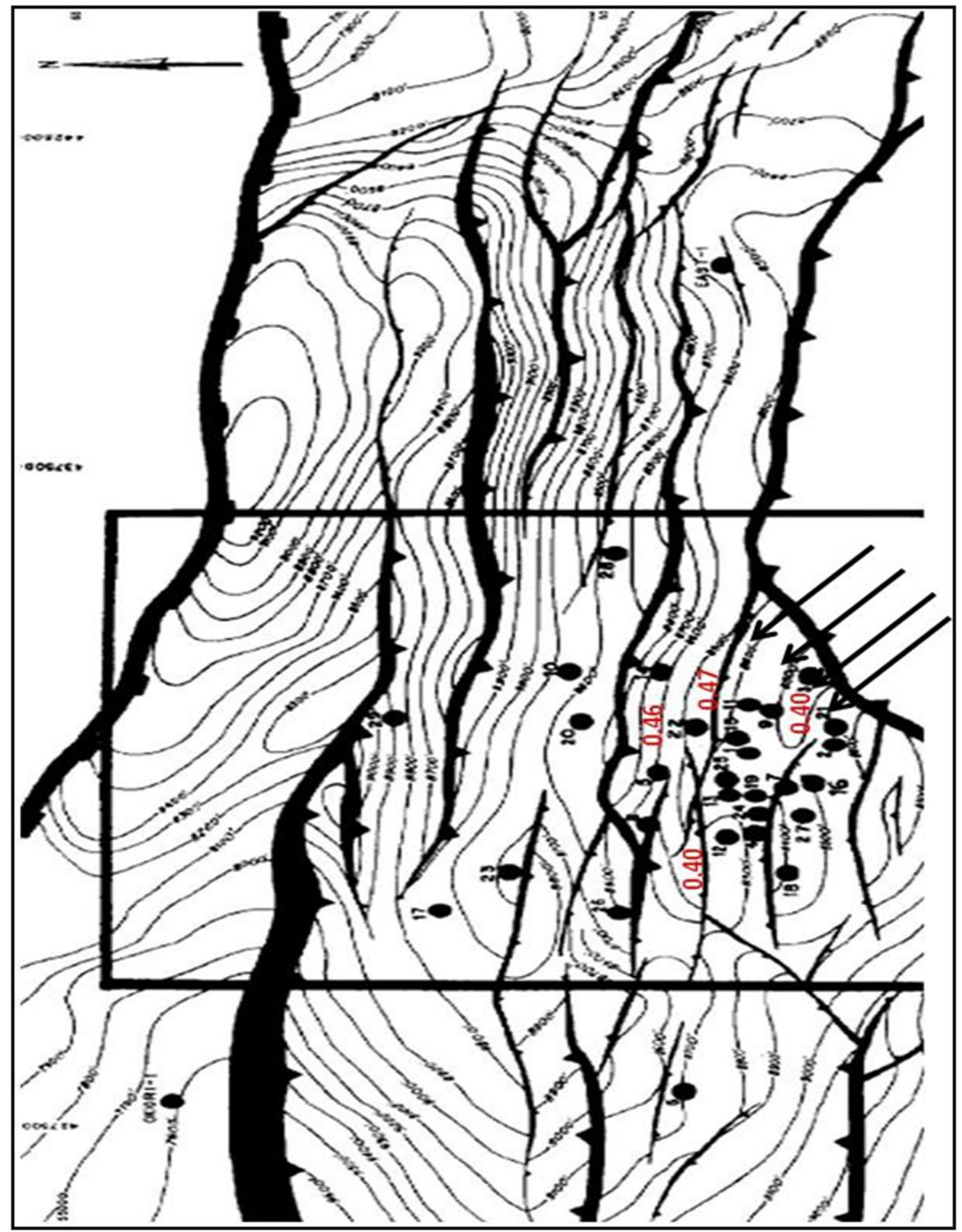

Fig. 7 The Isopach map of the Nembe Creek E1.0 reservoir showing the sterane maturity values indicating the direction of emplacement of petroleum into the reservoir in the SE-NW trend (Modified from Nelson 1980)

that the more mature petroleum which are the later charging fronts are always closer to the petroleum source kitchen (Larter and Aplin 1995). It can be suggested that the source kitchen of the Niger Delta petroleum is in the distal delta front, which consists the prodelta Akata marine shales. 


\section{Conclusion}

A suite of oils from the Kolo Creek E2.0 and Nembe Creek E1.0 reservoirs was analyzed for their maturity status. The maturity values expressed as percentage sterane isomerization values were posted on the Isopach map of the respective reservoirs. Maturity gradients were observed across the reservoirs, petroleum emplacement direction was inferred from the gradient and it was observed to be a SW-NE trend for the Kolo Creek reservoir and a SE-NW trend for the Nembe Creek reservoir. Obviously both trends are from the Southern part of the reservoir to the Northern part. Considering the petroleum system event chart for the critical moment in respect of the Niger Delta Petroleum system, the source kitchen has been inferred to be in the distal delta front which is mainly the Akata marine shales.

Acknowledgments The authors are grateful to Prof. L. C. Amajor of the Department of Geology, University of Port Harcourt, Nigeria for his contributions, also congratulate him on his peaceful retirement from the University services. We also thank the Petroleum technology development fund for sponsorship.

Open Access This article is distributed under the terms of the Creative Commons Attribution 4.0 International License (http:// creativecommons.org/licenses/by/4.0/), which permits unrestricted use, distribution, and reproduction in any medium, provided you give appropriate credit to the original author(s) and the source, provide a link to the Creative Commons license, and indicate if changes were made.

\section{References}

Abrakasa S (2006) newly identified molecular marker compound in some Nigerian oils. Nigeria Journal of Chemical Research 11:15-21

Akpabio1, I., Ejedawe, J., Ebeniro, J. 2013. In: Thermal state of the Niger Delta Basin proceedings, Thirty-Eighth Workshop On Geothermal Reservoir Engineering Stanford University, Stanford, California, February 11-13, 2013 Sgp-Tr-198

Amos-Uhegbu C, Igboekwe MU, Chukwu GU (2013) Aquifer Characterization and Quality Assessment of Groundwater in Umuahia-South Area of Abia State. Southern Nigeria. The Pacific. Journal of Science and Technology 14(2):642-653

Bustin RM (1998) Sedimentology and Characteriatics of dispersed organic matter in tertiary Niger Delta: Origin of source rocks in deltaic environment. AAPG Bulletin 72(3):277-298
Evamy RD, Haremboure J, Kamerling P, Knaap WA, Molloy FA, Rowlands PH (1978). Hydrocarbon habitat of tertiary Niger Delta, AAPG Bulletin, 62, No.1

Haack RC, P Srindararaman JO, Dedjomahor H, Xiao NJ, Gant ED, May, Kelsctu K (2000) Niger Delta petroleum systems, Nigeria. In: MR Mello, BJ Katz (eds) Petroleum systems of South Atlantic margins: AAPG Memoir 73, p. 273-231

Karlsen DA, Skeie JE, Backer-Owe K, Bjørlykke K, Olstad R, Berge K, Cecchi M, Vik E, Scaefer R (2004) Petroleum migration faults and overpressure. Part II. Case history: the Haltenbanken petroleum province, offshore Norway. In: Cubitt J, England W, Larter S (eds) 2004. Understanding petroleum reservoirs: towards an integrated reservoir engineering and geochemistry approach. Geological society of London, Special publications, 237, 305-372

Larter SR, Aplin AC (1995) Reservoir geochemistry: methods, applications and opportunities. In: Cubitt JM, England WA (eds) 1995, The Geochemistry of Reservoirs, Geological Society Special Publication No. 86, pp. 159-183

Mackenzie AS (1984) Application of biological markers in Petroleum geochemistry. In: Brooks J, Welte D (1984) Advances in organic geochemistry, 1, pp 155-215

Milkov AV, Goebel E, Dzou L, Fisher DV, Kutch A, McCaslin N, Bergman DF (2007) Compartmentalization and time-lapse geochemical reservoir surveillance of the Horn Mountain oil field. Deep-water Gulf of Mexico. AAPG Bulletin 91(6):847-876

Nelson PHH (1980) The role of reflection seismic in the development of Nembe Creek field Nigeria. AAPG Bulletin 30:565-576

Nwachukwu JI, Chukwra PI (1986) Organic matter of Agbada Formation, Niger Delta, Nigeria. AAPG Bulletin 70:48-55

Nyantakyi EK, Hue WS, Borkloe JK, Qin G, Cheng Han M (2013) Structural and Stratigraphic Mapping of Delta Field, Agbada Formation, Offshore Niger Delta. Nigeria. American Journal of Engineering Research. 2(11):204-215

Oboh FE (1993) Depositional history of the E2.0 reservoir in the Kolo Creek field, Niger Delta. J Pet Geol 16(2):197-212

Peters KE, Walters CC, Moldowan JM (2005). The biomarker guide volume 2, biomarkers and isotopes in petroleum exploration and earth history. United Kingdom, p. 475-1155

Shanmugam G (1985) Significance of coniferous rain forest and related organic matter in generating commercial quantities of oil, Gippsland Basin Australia. AAPG Bulletin 69:1241-1254

Tissot BP, Welte DH (1984) Petroleum formation and occurrence (2nd edition) Springer, $699 \mathrm{pp}$

Tuttle MLN, Charpentier RR, Brownfield ME (1999) The Niger Delta petroleum System: Niger Delta Province, Nigeria, Cameroon and Equatorial Guinea, Africa. Open file report 99-50-H, US Geological Survey

Zumberge J (1987) Terpenoid biomarker distribution in low maturity crude oils. Org Geochem 11:474-496 